\title{
A city-level analysis of air pollution, climate and COVID-19 early spread during the
}

\section{Spanish lockdown}

\author{
Álvaro Briz-Redón ${ }^{1, \mathbb{I}}$, Carolina Belenguer-Sapiña ${ }^{2, \mathbb{I l}}$, Ángel Serrano-Aroca ${ }^{3, *}$ \\ ${ }^{1}$ Statistics Office, City Council of Valencia, c/Arquebisbe Mayoral, 2, Valencia 46002, Spain \\ ${ }^{2}$ Department of Analytical Chemistry, Faculty of Chemistry, University of Valencia, \\ c/Doctor Moliner 50, Burjassot, Valencia 46100, Spain \\ ${ }^{3}$ Centro de Investigación Traslacional San Alberto Magno, Universidad Católica de Valencia \\ San Vicente Mártir, c/Guillem de Castro 94, Valencia 46001, Spain. \\ "These authors contributed equally \\ * Corresponding author
}




\begin{abstract}
The COVID-19 outbreak has escalated into the worse pandemic of the present century. The fast spread of the new SARS-CoV-2 coronavirus has caused devastating health and economic crises all over the world, with Spain being one of the worst affected countries in terms of confirmed COVID-19 cases and deaths per inhabitant. In this situation, the Spanish Government declared the lockdown of the country. The variations of air pollution in terms of fine particulate matter $\left(\mathrm{PM}_{2.5}\right)$ levels in seven cities of Spain are analyzed here considering the effect of meteorology during the national lockdown. The possible associations of $\mathrm{PM}_{2.5}$ pollution and climate with COVID-19 accumulated cases were also analyzed. While the epidemic curve was flattened, the results of the analysis show that the 4-week Spanish lockdown significantly reduced the $\mathrm{PM}_{2.5}$ levels in only one of the cities despite the drastically reduced human activity in good agreement with our previous study of changes in air quality in terms of $\mathrm{CO}, \mathrm{SO}_{2}, \mathrm{PM}_{10}, \mathrm{O}_{3}$ and $\mathrm{NO}_{2}$ levels. Furthermore, no associations between either $\mathrm{PM}_{2.5}$ exposure or environmental conditions and COVID-19 transmission were found during the early spread of the pandemic.
\end{abstract}

Keywords: COVID-19 spread; $\mathrm{PM}_{2.5}$ pollution; environmental conditions; SARS-CoV-2; climate 


\section{Introduction}

The global pandemic of the SARS-CoV-2 coronavirus causing COVID-19, first announced in Wuhan, China, in December 2019(WHO, 2020a), continues to spread in more than 200 countries(WHO, 2020b). Spain confirmed 314,362 COVID-19 infections and 28,503 death people(ISCIII, n.d.) on August 9, 2020, which is one of the largest mortality rates of this emerging disease. Due to the growing pandemic, governments have been forced to react with lighter or stronger control measures influenced by their cultural backgrounds(Chiu et al., 2020). The government of Spain declared a lockdown on March 14, 2020. Extraordinary control policies were executed in an effort to reduce COVID-19 transmission. At the beginning of the lockdown, from March 15 to March 29, 2020, named here as minor lockdown, people were recommended to work from home, and other measures such as travel restrictions, isolation, and quarantine of patients, cancellation of private and public events, online education, the closing of restaurants, bars and pubs, or the prohibition of public congregations, were imposed. During those two weeks, only essential products could be sold in supermarkets and drugstores, and only a small amount of activities were allowed. During the last two weeks of the lockdown, from March 30 to April 12, 2020, named here as major lockdown, the Spanish Government imposed more severe restrictions due to the national emergency caused by the collapse of the health system. This situation forced people to stay at home (except for very limited purposes) and only essential work such as healthcare and social care sectors, police and armed forces, water and electricity supply was allowed. Besides, important industrial activities such as construction were forbidden. These unprecedented measures gave positive results and flattened the epidemic curve after a month 
medRxiv preprint doi: https://doi.org/10.1101/2020.08.09.20171041; this version posted August 19, 2020. The copyright holder for this preprint

of lockdown(Tobías, 2020). In short, the pandemic has definitely caused significant behavioral variations in society and could provide a useful insight into how we can make our production methods more sustainable(Sarkis et al., 2020). The impact of particulate matter (PM) on health is well-known(Manisalidis et al., 2020) in terms of its effects on morbidity and mortality. Two sizes of particulate matter are used to analyze air quality; fine particulate matter or $\mathrm{PM}_{2.5}$, with a diameter of $2.5 \mu \mathrm{m}$ or less, and coarse particles or $\mathrm{PM}_{10}$, with a diameter of $10 \mu \mathrm{m}$ or less. However, the former is more worrying because their small size allows them to penetrate deeper into the human respiratory system via inhalation, which can potentially promote respiratory diseases(Chai et al., 2019; Dominici et al., 2006; Horne et al., 2018) such as COVID-19. Thus, it is of note that citizens exposed to a high concentration of $\mathrm{PM}_{2.5}$ are more prone to developing chronic respiratory diseases favorable to infective agents(Mehmood et al., 2020). Long-term exposure to these small particles can produce a chronic inflammatory stimulus, especially in unhealthy people(Conticini et al., 2020).In addition, short-term exposure to $\mathrm{PM}_{2.5}$ particles may also increase susceptibility to infections(Chen et al., 2020). Indeed, this type of pollution can harm human airways, promoting viral infections, and diminish the immune response(Liu et al., 2019; Mehmood et al., 2020; Sedlmaier et al., 2009). The World Health Organization's air quality guidelines recommend that $\mathrm{PM}_{2.5}$ concentration should not exceed a $10 \mu \mathrm{g} / \mathrm{m}^{3}$ annual mean and 25 $\mu \mathrm{g} / \mathrm{m}^{3}$ 24-hour mean(World Health Organization, 2018). Due to combustion processes, road traffic is the main emission source of atmospheric $\mathrm{PM}_{2.5}$ (Nicolás et al., 2020). Other sources of $\mathrm{PM}_{2.5}$ in urban environments include Sahara dust events(Fenech and Aquilina, 2020; Nicolás et al., 2020), shipping(Viana et al., 2020), secondary inorganic aerosol or biomass burning(Liu et al., 2020), combustion processes in thermal power stations and other industrial sectors, the transport of anthropogenic aerosols from central Europe to Mediterranean areas, 
medRxiv preprint doi: https://doi.org/10.1101/2020.08.09.20171041; this version posted August 19, 2020. The copyright holder for this preprint

and certain agricultural activities(García et al., 2019). Spain, which still consumes a considerable amount of fossil fuels, is quite near to the Sahara Desert and has approximately 47 million inhabitants. Thus, it is in a high-risk zone of pollution episodes(Lemou et al., 2020). The Mediterranean zone has been identified as a crossroads of air masses with many kinds of aerosols caused by many anthropogenic and natural sources, such as the resuspension of dust from Africa, the production of sea salt, industrial and urban aerosols, fires, and smoke from Eastern Europe(Lemou et al., 2020). The zone is also known for its intensive shipping traffic, near a densely populated and environmentally sensitive area with low atmospheric dispersion(Viana et al., 2020). Since Spain has been positioned as one of the ten most climatically differing nations (Ministerio de Medio Ambiente y Medio Rural y Marino. AEMET, 2011), it is necessary to take meteorological factors(Briz-Redón and Serrano-Aroca, 2020a) into account when evaluating atmospheric pollutant concentrations. We have recently demonstrated that the Spanish lockdown did not decrease air pollution $\left(\mathrm{NO}_{2}, \mathrm{CO}, \mathrm{SO}_{2}\right.$, and $\left.\mathrm{PM}_{10}\right)$ considering meteorological factors on the pollutants' levels(BrizRedón et al., 2020). Furthermore, the $\mathrm{O}_{3}$ levels were generally increased during this period. In the current paper, we focus on the variations of air pollution in terms of fine particulate matter, wich could be associated with the COVID-19 spread(Mehmood et al., 2020), in several representative Spanish cities during the lockdown using $\mathrm{PM}_{2.5}$ pollution and COVID19 data. Meteorological parameters, which significantly affect air pollution (Shi et al., 2018; M. Wang et al., 2020; Wang et al., 2019) have also been taken into account. Several studies in the same research line have shown evidence of significant reductions of severe $\mathrm{PM}_{2.5}$ pollution during COVID-19 lockdowns in other countries, such as India(Mahrati et al., 2020; Sharma et al., 2020) and Malaysia(Abdullah et al., 2020). However, it has been reported an increased of the $\mathrm{PM}_{2.5}$ levels in Tehran (Faridi et al., 2020) due to the reduction of public 
transportation use and thus increase of traveling by private vehicle, and in other countries such as China, which probably applied one of the strictest lockdown measures, the fine particulate matter in the atmosphere was not significantly reduced(P. Wang et al., 2020). On the other hand, COVID-19 daily new cases have been positively related with $\mathrm{PM}_{2.5}$ levels in 355 municipalities in the Netherlands(Cole et al., 2020), in Milan(Zoran et al., 2020) and in China(Zhu et al., 2020). However, additional research is needed to test the exploratory associations found between air pollution and COVID-19 prevalence so far(Hendryx and Luo, 2020). Therefore, in this paper, we also explore the possible impact of $\mathrm{PM}_{2.5}$ exposure and the effect of environmental conditions (temperature, wind, precipitation, sunlight, pressure) on the COVID-19 early spread.

\section{Data}

\subsection{PM 2.5 pollution}

Seven major Spanish cities were considered in this study (see Figure 1). 


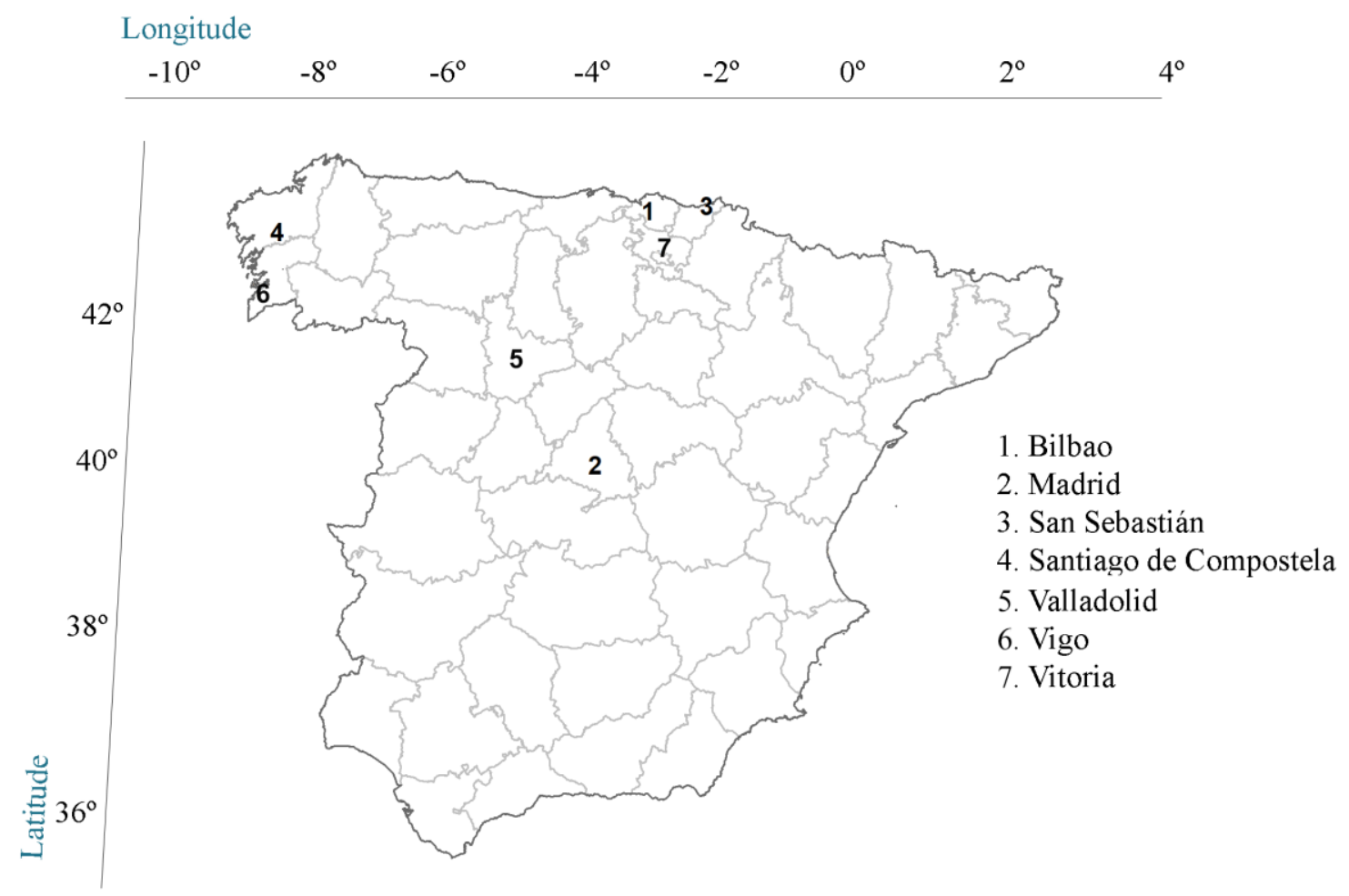

Figure 1. Map of Spain with the seven cities considered for the $\mathrm{PM}_{2.5}$ pollution analysis. Location coordinates are those of the pollution station. The provincial borders are shown in grey.

Table 1 shows that the information of each selected city with populations (on January 1, 2019) that vary from 97,260 to $3,266,126$ inhabitants(INE, 2019).

\begin{tabular}{cccccc}
\hline SPANISH CITY & PROV & POP & QS & LO & LA \\
& & & & & \\
\hline Bilbao & Biscay & 346,843 & Europa & -2.9024 & 43.2549 \\
Madrid - capital city & Madrid & $3,266,126$ & Escuelas Aguirre & -3.6823 & 40.4217 \\
San Sebastián & Gipuzkoa & 187,415 & Avenida Tolosa & -2.0109 & 43.3094 \\
Santiago de Compostela & A Coruña & 97,260 & S. Caetano & -8.5311 & 42.8878 \\
Valladolid & Valladolid & 298,412 & La Rubia II & -4.7406 & 41.6300 \\
Vigo & Pontevedra & 295,364 & Coia & -8.7421 & 42.8548
\end{tabular}


medRxiv preprint doi: https://doi.org/10.1101/2020.08.09.20171041; this version posted August 19, 2020. The copyright holder for this preprint (which was not certified by peer review) is the author/funder, who has granted medRxiv a license to display the preprint in perpetuity.

It is made available under a CC-BY-NC-ND 4.0 International license .

Vitoria $\quad$ Álava $\quad 251,774 \quad$ Avenida Gasteiz $\quad-2.6807 \quad 42.8548$

Table 1. Spanish city, province (PROV), population (POP, on January 1, 2019), and longitude (LO) and latitude (LA) of the air quality stations (QS) selected for the study.

Table 2 provides a city-level statistical summary of the $\mathrm{PM}_{2.5}$ levels in each of the periods considered for the analysis.

\begin{tabular}{c|ccc|ccc|ccc}
\hline \multirow{2}{*}{ Spanish city } & \multicolumn{3}{|c|}{ Normal period } & \multicolumn{3}{c|}{ Minor lockdown } & \multicolumn{3}{c}{ Major lockdown } \\
& Mean & $\mathbf{1}^{\text {st }} \mathbf{Q}$ & $\mathbf{3}^{\text {rd }} \mathbf{Q}$ & Mean & $\mathbf{1}^{\text {st }} \mathbf{Q}$ & $\mathbf{3}^{\text {rd }} \mathbf{Q}$ & Mean & $\mathbf{1}^{\text {st }} \mathbf{Q}$ & $\mathbf{3}^{\text {rd }} \mathbf{Q}$ \\
\hline Bilbao & 9.13 & 6.00 & 12.50 & 13.93 & 11.00 & 17.00 & 8.14 & 6.25 & 9.75 \\
Madrid & 11.51 & 6.00 & 14.00 & 6.60 & 4.50 & 8.50 & 7.00 & 5.00 & 9.00 \\
San Sebastián & 8.95 & 6.00 & 11.00 & 13.17 & 10.75 & 15.50 & 8.64 & 7.00 & 10.00 \\
Santiago de Compostela & 12.64 & 8.20 & 17.00 & 15.18 & 13.00 & 18.00 & 9.01 & 7.23 & 9.85 \\
Valladolid & 11.30 & 6.50 & 15.00 & 11.40 & 8.50 & 13.00 & 6.14 & 5.00 & 7.00 \\
Vigo & 9.11 & 6.45 & 12.00 & 11.93 & 9.20 & 13.50 & 6.21 & 5.00 & 6.78 \\
Vitoria & 7.33 & 4.25 & 10.00 & 10.87 & 9.00 & 13.50 & 6.36 & 4.50 & 7.00 \\
\hline
\end{tabular}

Table 2. City-level statistical summary of $\mathrm{PM}_{2.5}$ levels in terms of mean value, $1^{\text {st }}$ quartile $\left(1^{\text {st }} \mathrm{Q}\right)$, and $3^{\text {rd }}$ quartile $\left(3^{\text {rd }} \mathrm{Q}\right)$ at each of the different periods (normal, minor and major lockdown) considered for the analysis

$\mathrm{PM}_{2.5}$ pollution data was obtained from official web pages: Bilbao(Euskadi.eus, 2020); Madrid(Ayuntamiento de Madrid, 2020); San Sebastián(Euskadi.eus, 2020); Santiago (Xunta de Galicia, 2020); Valladolid(Junta de Castilla y León, 2020); Vigo(Xunta de Galicia, 2020) and Vitoria(Euskadi.eus, 2020). This pollution data was obtained from a traffic station of each city (see Table 1), whose pollution levels are mainly the consequence of traffic emissions(UK Dep. for Environment Food and Rural Affairs, 2020). Every day, $\mathrm{PM}_{2.5}$ (in $\mu \mathrm{g} / \mathrm{m}^{3}$ ) were collected from each station from March 4 to April 14, 2019, and from March 2 to April 12, 2020, using the sampling method defined by the current Directive 2015/1480(2015/1480/UE, 2015) instead of the previous(2008/50/CE, 2008), following the gravimetric method of determining $\mathrm{PM}_{2.5}$ mass fraction in suspended particulate matter (EN 12341:2014, 2014). The measurements are commonly performed with active samplers 
medRxiv preprint doi: https://doi.org/10.1101/2020.08.09.20171041; this version posted August 19, 2020. The copyright holder for this preprint (which was not certified by peer review) is the author/funder, who has granted medRxiv a license to display the preprint in perpetuity.

It is made available under a CC-BY-NC-ND 4.0 International license .

operating at $2.3 \mathrm{~m}^{3} / \mathrm{h}$ over a sampling period of $24 \mathrm{~h}$. The range of application of this European Standard is from $1 \mu \mathrm{g} / \mathrm{m}^{3}$ (detection method limit) up to approximately $120 \mu \mathrm{g} / \mathrm{m}^{3}$.

\subsection{Meteorological data}

The API of the OpenData platform of the State Meteorological Agency was used to download the meteorological data necessary for this analysis. One meteorological station per city was selected for the meteorological variables considered in this study: temperature, precipitation, wind velocity, min, and max atmospheric pressure, and sunlight time, that is, number of hours with a solar irradiance over $120 \mathrm{~W} / \mathrm{m}^{2}$. The minimum pressure was discarded for the analysis because of the high correlation (very close to 1) between the maximum and minimum pressure values. Table 3 provides a statistical summary of the meteorological variables considered.

\begin{tabular}{|c|c|c|c|c|c|c|c|c|c|c|c|c|c|c|c|}
\hline \multirow{2}{*}{ Spanish city } & \multicolumn{3}{|c|}{$\mathbf{T}\left({ }^{\circ} \mathbf{C}\right)$} & \multicolumn{3}{|c|}{ PR(mm) } & \multicolumn{3}{|c|}{ WS $(\mathbf{k m} / \mathbf{h})$} & \multicolumn{3}{|c|}{ SH (h) } & \multicolumn{3}{|c|}{ MP (hPa) } \\
\hline & Mean & $\mathbf{1}^{\text {st }} \mathbf{Q}$ & $3^{\text {rd }} Q$ & Mean & $1^{\text {st }} \mathbf{Q}$ & $3^{\text {rd }} \mathbf{Q}$ & Mean & $\mathbf{1}^{\text {st }} \mathbf{Q}$ & $3^{\text {rd }} \mathbf{Q}$ & Mean & $\mathbf{1}^{\text {st }} \mathbf{Q}$ & $3^{\text {rd }} \mathbf{Q}$ & Mean & $1^{\text {st }} \mathbf{Q}$ & $\mathbf{3}^{\text {rd }} \mathbf{Q}$ \\
\hline Bilbao & 12.2 & 10.2 & 14.2 & 3.1 & 0.0 & 3.1 & 3.5 & 2.2 & 3.9 & 4.5 & 0.9 & 7.6 & 1017.1 & 1012.6 & 1022.7 \\
\hline Madrid & 11.3 & 9.7 & 13.2 & 1.4 & 0.0 & 0.5 & 3.3 & 1.9 & 4.2 & 7.1 & 3.4 & 11.0 & 952.8 & 949.2 & 957.8 \\
\hline San Sebastián & 11.2 & 9.3 & 13.0 & 3.92 & 0.0 & 5.1 & 4.5 & 2.8 & 5.3 & 5.3 & 1.4 & 9.0 & 990.7 & 986.3 & 996.2 \\
\hline Santiago de Compostela & 10.3 & 8.4 & 12.5 & 4.2 & 0.00 & 3.4 & 2.9 & 1.9 & 3.6 & 5.9 & 2.4 & 10.4 & 978.5 & 974.2 & 983.3 \\
\hline Valladolid & 10.9 & 7.9 & 11.6 & 1.2 & 0.0 & 1.2 & 2.2 & 1.4 & 2.8 & 7.3 & 4.3 & 10.6 & 935.9 & 932.0 & 941.1 \\
\hline Vigo & 11.9 & 10.0 & 13.5 & 5.2 & 0.0 & 3.9 & 3.5 & 2.8 & 3.9 & 6.8 & 2.7 & 10.6 & 990.9 & 986.3 & 995.4 \\
\hline Vitoria & 8.6 & 6.6 & 10.4 & 1.4 & 0.0 & 1.0 & 3.6 & 2.5 & 4.2 & 6.2 & 3.0 & 9.8 & 961.7 & 957.6 & 966.9 \\
\hline
\end{tabular}

Table 3. Summary of the meteorological variables (temperature (T), Precipitation (PR), Wind speed (WS), sunlight hours (SH) and maximum pressure (MP)) considered for the study in terms of mean value, $1^{\text {st }}$ quartile $\left(1^{\text {st }} \mathrm{Q}\right)$, and $3^{\text {rd }}$ quartile $\left(3^{\text {rd }} \mathrm{Q}\right)$ during the entire study period.

\subsection{COVID-19 data}

COVID-19 data was also downloaded from multiple local and regional webpages: Bilbao(Euskadi, 2020), Madrid(Datos Abiertos Comunidad de Madrid, 2020), San Sebastián(Euskadi, 2020), Santiago de Compostela(Galicia, 2020), Valladolid(JCyL, 2020), 
medRxiv preprint doi: https://doi.org/10.1101/2020.08.09.20171041; this version posted August 19, 2020. The copyright holder for this preprint (which was not certified by peer review) is the author/funder, who has granted medRxiv a license to display the preprint in perpetuity.

It is made available under a CC-BY-NC-ND 4.0 International license .

Vigo(Galicia, 2020), and Vitoria(Euskadi, 2020). Data was collected for the period comprised from March 18 to April 12, 2020, and corresponded to the number of accumulated COVID-19 cases in each city.

\section{Methods}

\section{1. $R$ programming language}

The R programming language(Team, 2020) was used for the statistical analysis with several R packages: effects(Fox and Weisberg, 2018), ggplot2(Wickham, 2016), INLA(Lindgren and Rue, 2015; Rue et al., 2009), lubridate(Grolemund and Wickham, 2011), RCurl(Lang and the CRAN team, 2015), sjPlot(Ludecke, 2016) and XML(Lang, 2020).

\subsection{Modeling pollution levels}

In order to discriminate between the effects of meteorology and lockdown, the meteorological variables (temperature, precipitation, wind velocity, sunlight time, or atmospheric pressure), which modify pollutant levels (Venter et al., 2020), were considered in the statistical model. Weekend days were also considered because of their reduced pollutant levels as a result of less road traffic. Thus, the daily $\mathrm{PM}_{2.5}$ pollutant levels of the seven cities were fitted through a statistical model considering meteorological variables, weekend days, and lockdown periods. The $\mathrm{PM}_{2.5}$ pollutant levels for a city $i$ on date $t$ were modeled by Equation (1), including quadratic terms capable of capturing non-linear relationships between the meteorological variables and the $\mathrm{PM}_{2.5}$ level. 


$$
\begin{aligned}
& \left(\mathrm{PM}_{2.5}\right)_{i t}=\alpha+\beta_{11} \text { Temperature }_{i t}+\beta_{12} \text { Temperature }^{2}{ }_{i t}+\beta_{21} \text { Rain }_{i t}+\beta_{22} \\
& \operatorname{Rain}^{2}{ }_{i t}+\beta_{31} \operatorname{Wind}_{i t}+\beta_{32} \mathrm{Wind}^{2}{ }_{i t}+\beta_{41} \text { Sunlight }_{i t}+\beta_{42} \text { Sunlight }^{2}{ }_{i t}+\beta_{51} \\
& \text { Max_pressure }_{i t}+\beta_{52} \text { Max_pressure }_{i t}^{2}+\gamma \text { Weekend }_{t}+\rho_{i} \text { City }_{i}+\left(\delta_{1}+\right. \\
& \left.\delta_{1 i}\right) \text { Minor_lockdown }+\left(\delta_{2}+\delta_{2 i}\right) \text { Major_lockdown } \mathrm{n}_{t}
\end{aligned}
$$

In this regression model, $\alpha$ is the global intercept of the model, $\beta_{k j}(k=1,2,3,4,5$ and $j=1$, 2) quantifies the corresponding meteorological covariate effect (in quadratic form, or not) on the $\left(\mathrm{PM}_{2.5}\right)_{i t}$ values, $\gamma$ quantifies weekend days effect on the $\left(\mathrm{PM}_{2.5}\right)_{i t}$ values, $\rho_{i}$ represents the city-specific effect at no lockdown $\mathrm{PM}_{2.5}$ levels, $\delta_{1}$ and $\delta_{2}$ indicate the overall lockdown effect (minor and major, respectively) on $\left(\mathrm{PM}_{2.5}\right)_{i t}$ levels, and $\delta_{1 i}$ and $\delta_{2 i}$ indicate the city-specific effect (minor and major, respectively) on the $\left(\mathrm{PM}_{2.5}\right)$ it level. Bank holidays were computed as weekend days. Therefore, this model estimates the variations of $\mathrm{PM}_{2.5}$ pollution levels because of lockdown while simultaneously accounting for week-day and meteorological effects.

\subsection{Modeling COVID-19 spread}

The association between COVID-19 spread and the $\mathrm{PM}_{2.5}$ levels and environment was also studied for all the cities included in the study. Hence, the number of accumulated COVID19 cases in each city was modelled in terms of each of the environmental covariates available (temperature, rain, wind velocity, sunlight time, maximum atmospheric pressure, and $\mathrm{PM}_{2.5}$ level) through a Poisson model. Thus, the accumulated COVID-19 cases on date $t, y_{t}$, was modelled as follows:

$$
\begin{gathered}
y_{t}=\operatorname{Po}\left(\mu_{t}\right) \\
\log \left(\mu_{t}\right)=\alpha+\beta x_{t}+\delta_{t}
\end{gathered}
$$


where $\alpha$ is the global intercept of the model, $x_{t}$ represents the environmental covariate, $\beta$ refers to the coefficient that measures the magnitude of the effect of $x_{t}$ on $\log \left(\mu_{t}\right)$, and $\delta_{t}$ is a temporally-structured effect for day $t$ to control for serial correlation, which was defined by a first-order random walk. Lagged covariate effects were considered in the model by replacing the term $x_{t}$ by $x_{t-7}$, and $x_{t-14}$, which allows assessing the possible effect of the environmental conditions on the previous two weeks on the total number of cases reported on date $t$. The model described by Equation (2) was fitted using the Integrated Nested Laplace Approximation (INLA) method(Lindgren and Rue, 2015; Rue et al., 2009).

\section{Results and discussion}

\subsection{Global effects}

A stepwise algorithm was applied to the regression model represented by Equation (1) to find the subset of the variables providing the best model in terms of the Akaike information criterion. The overall variables included in this model and the coefficients associated with each one are shown in Table 4.

\begin{tabular}{|c|c|c|}
\hline & Estimate & $p$-value \\
\hline$($ Intercept $)(\alpha)$ & -943.8003 & 0.0521 \\
\hline Temperature $\left(\beta_{11}\right)$ & 0.7071 & 0.0393 \\
\hline Temperature $^{2}\left(\beta_{12}\right)$ & -0.0241 & 0.1202 \\
\hline Wind speed $\left(\beta_{31}\right)$ & -1.0710 & 0.0002 \\
\hline Wind speed $^{2}\left(\beta_{32}\right)$ & 0.0402 & 0.1156 \\
\hline Sunlight hours ${ }^{2}\left(\beta_{42}\right)$ & 0.0322 & 0.0000 \\
\hline Max Pressure $\left(\beta_{51}\right)$ & 1.8652 & 0.0608 \\
\hline Max Pressure $^{2}\left(\beta_{52}\right)$ & -0.0009 & 0.0717 \\
\hline Weekend day $(\gamma)$ & 0.8308 & 0.0215 \\
\hline Minor lockdown day $\left(\delta_{1}\right)$ & 4.3791 & 0.0001 \\
\hline Major lockdown day $\left(\delta_{2}\right)$ & -1.4703 & 0.2328 \\
\hline
\end{tabular}

Table 4. Global effects estimated between variables and fine particulate matter with Equation (1). The estimated model coefficients are shown together with the associated $p$-values. 
First, it is worth noting that the two precipitation-related variables were discarded, suggesting the absence of an association between precipitation and $\mathrm{PM}_{2.5}$ values. The model also suggests that temperature, wind speed, the number of sunlight hours, and the maximum pressure have a quadratic relationship with $\mathrm{PM}_{2.5}$ levels. Thus, for the range of values attained by these meteorological variables during the period under study, the coefficients estimated for the linear and quadratic forms of the variables indicate that higher values of either temperature, sunlight hours, or maximum pressure are associated with higher $\mathrm{PM}_{2.5}$ levels, whereas higher wind speed values are associated with lower $\mathrm{PM}_{2.5}$ levels. The results obtained mostly agree with other studies in the literature. Thus, regarding the positive association of $\mathrm{PM}_{2.5}$ with temperature and sunlight hours, dry sunny weather frequently leads to prevent the vertical dispersion of pollutants due to thermal inversion(Mao et al., 2020) and increases their concentration, generating significant smog episodes. Indeed, sunny weather also favors photochemical reactions(P. Wang et al., 2020; Xu et al., 2020) while dry conditions prolong aerosols and atmospheric loadings(Lemou et al., 2020). The increase of wind speed can also decrease $\mathrm{PM}_{2.5}$ levels(Radzka, 2020; Yousefian et al., 2020), while lower wind speeds can promote a reduction of particulate matter in the air because of a significant increase of deposition(Xu et al., 2020). The rise of atmospheric pressure seems to positively affect PM formation(Hoque et al., 2020).

\subsection{Coefficients of determination}

Table 5 shows the coefficients of determination $\left(R^{2}\right)$ for each model using $\mathrm{PM}_{2.5}$ data with Equation (1).

\begin{tabular}{lc}
\hline Model & $\boldsymbol{R}^{\mathbf{2}}$ \\
\hline Meteorological & 0.3069
\end{tabular}




$$
\begin{array}{lc}
\text { Meteorological + Weekend } & 0.3166 \\
\text { Meteorological + Weekend + City } & 0.3846 \\
\text { Meteorological + Weekend + City * Lockdown } & 0.4768
\end{array}
$$

Table 5. Coefficients of determination $\left(R^{2}\right)$ for each model using $\mathrm{PM}_{2.5}$ data with Equation (1).

From this analysis, it follows that the $\mathrm{PM}_{2.5}$ levels seem to be quite dependent on meteorological factors while the inclusion of city-level and lockdown effects is fundamental to improve $R^{2}$ values.

\subsection{Marginal city-specific effect for the PM2.5 pollutant}

The minor lockdown led to overall increases in $\mathrm{PM}_{2.5}$ levels in the cities considered (see results of Table 4). Nevertheless, the full analysis of the proposed model requires the consideration of the city-specific coefficients omitted in Table 4. In fact, the global cityspecific effects and the global period (no lockdown, minor, or major lockdown) effects were employed for the estimation of the city-specific marginal effects of the $\mathrm{PM}_{2.5}$ levels. The cityspecific effects of the city-period interactions were also considered in this analysis. These results show the $\mathrm{PM}_{2.5}$ variations due to the COVID-19 lockdown in each city. Figure 2 shows these city-specific marginal effects with the $95 \%$ confidence intervals estimated with the Equation (1) for the $\mathrm{PM}_{2.5}$ pollution levels during the minor lockdown, major lockdown, and no lockdown. 


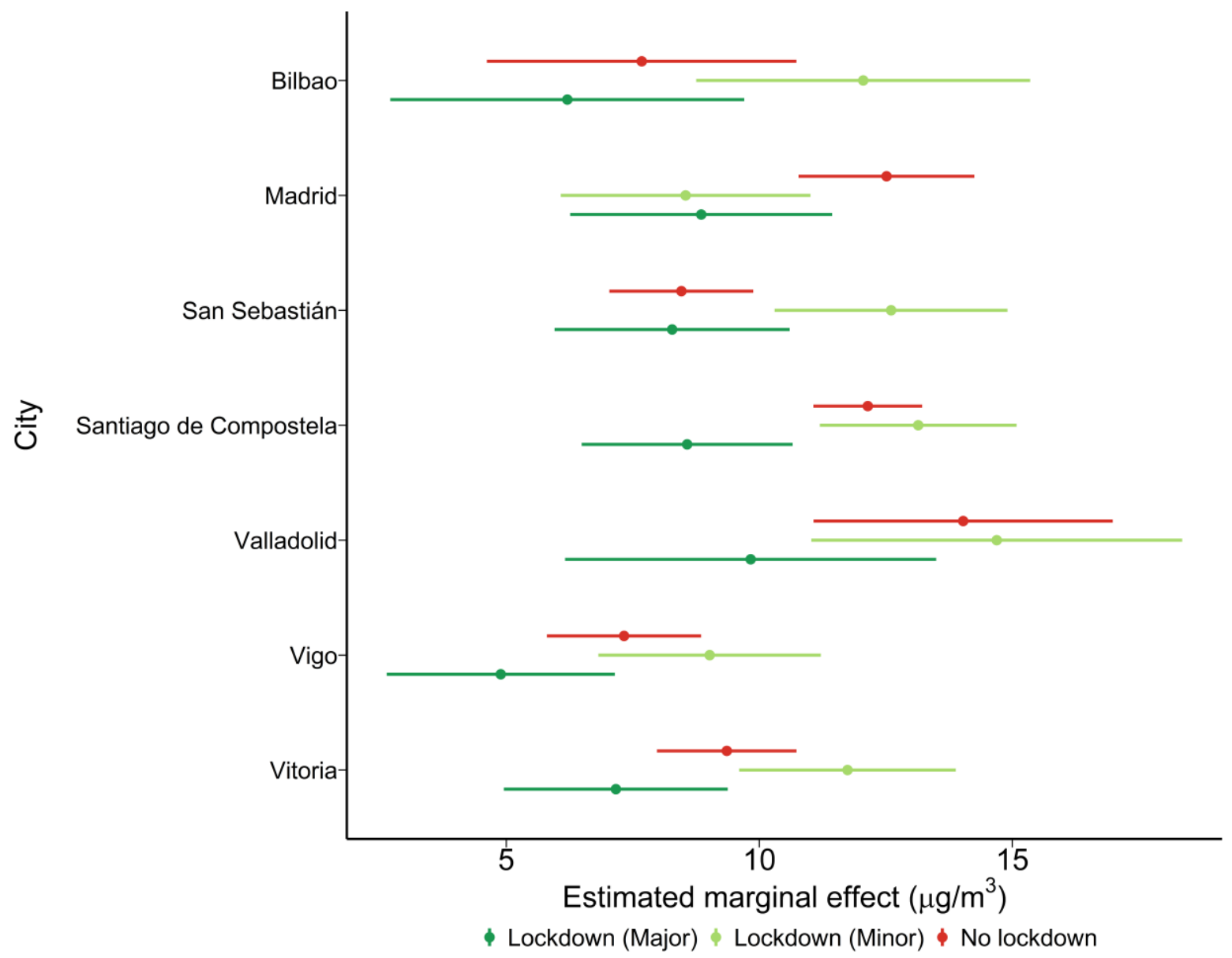

Figure 2. City-specific marginal effects estimated for the $\mathrm{PM}_{2.5}$ pollution levels during the minor lockdown, major lockdown, and no lockdown periods. Marginal effects are statistically different when there is no overlapping of the confidence intervals.

The point estimates represented in this figure show the adjusted effect of the combination of city and period under study on $\mathrm{PM}_{2.5}$ pollution levels. The differences between $\mathrm{PM}_{2.5}$ concentrations during the normal period, minor, and major lockdown were not significantly different in many of the cities. However, there was a rising trend in the minor lockdown $\mathrm{PM}_{2.5}$ levels in some cities considering meteorological and week-day effects, especially in Bilbao and San Sebastián. Considering that relative humidity was not included in the linear regression, these results may simply be an artifact due to high relative humidity episodes that can improve the aqueous-phase oxidation of pollutants such as $\mathrm{SO}_{2}$ and $\mathrm{PM}_{2.5}$ levels( $\mathrm{P}$. 
Wang et al., 2020). Both are coastal cities in the north of Spain, where higher humidity is usual and are more likely to receive atmospheric particles from shipping and sea salt, two of the main sources of the pollutant analyzed. On the other hand, the major lockdown period led to a general reduction in fine particulate matter, although only one statistically significant reduction was found in Santiago de Compostela, from $12.14 \pm 0.55$ to $8.57 \pm 1.06 \mu \mathrm{g} / \mathrm{m}^{3}$, in terms of marginal effects. This reduction of $\mathrm{PM}_{2.5}$ particles must be related to the drastically reduced human activity during the Spanish lockdown (P. Wang et al., 2020). However, the relationship between traffic and anthropogenic activity with particulate matter sources and particle size is not necessarily unequivocal (Nicolás et al., 2020), so that the variations shown may not always be as clear as might be expected. Nevertheless, the reduction of this fine particulate matter was not expected to be very high because these inhalable particles are emitted in large volumes and persist in the air for longer periods, which means they can spread easier(Xiao et al., 2018). In fact, these low reductions are in good agreement with our previous study of variations in air quality in terms of $\mathrm{PM}_{10}$ levels during this period (BrizRedón et al., 2020).

\subsection{Association analysis of PM2.5 pollution and weather patterns with COVID-19 spread}

Figure 3 shows that the strict national lockdown imposed in Spain flattened the epidemic curve as expected by the Spanish authorities. 


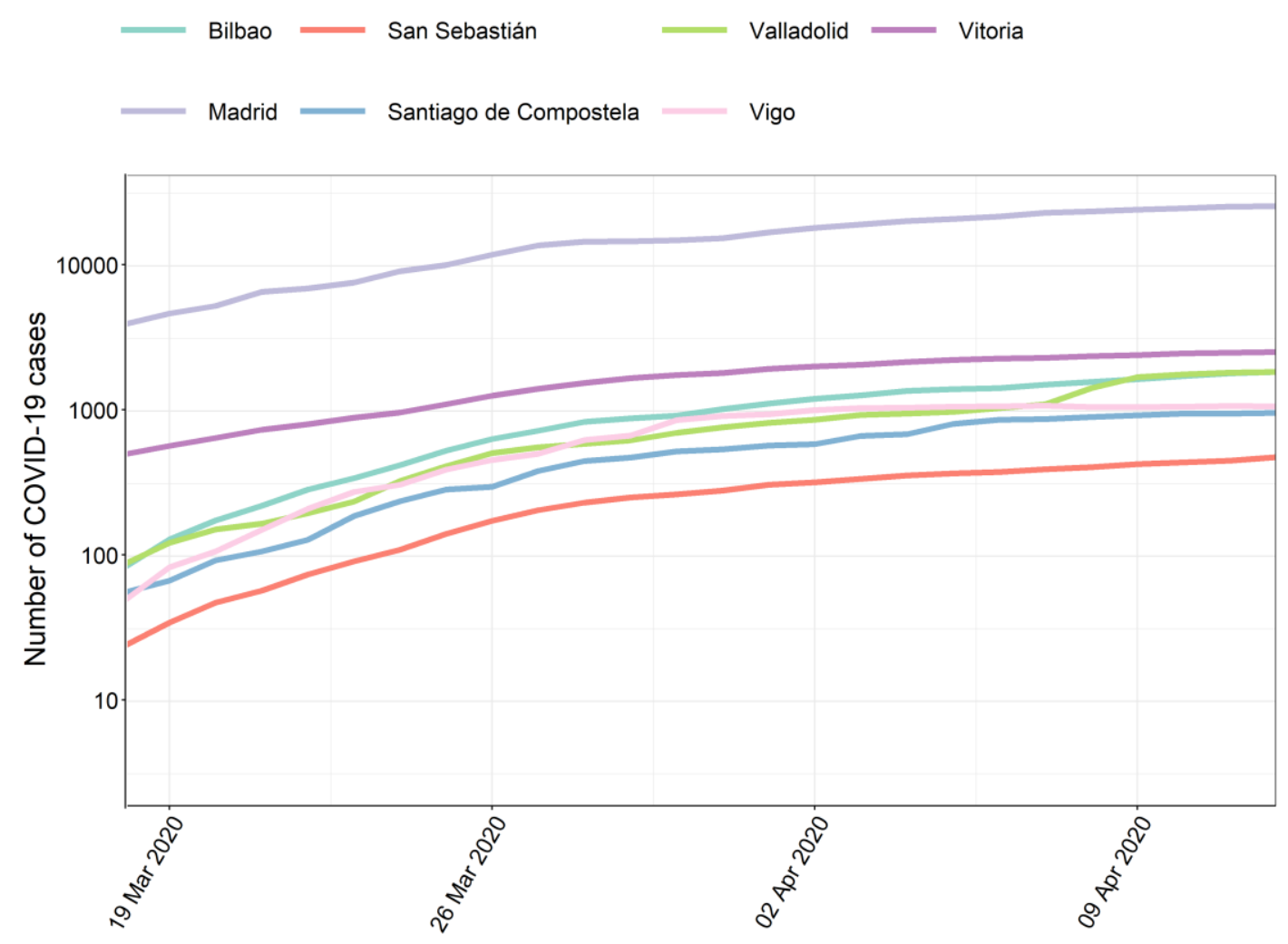

Figure 3. COVID-19 data used for the association study with COVID-19 accumulated cases for the seven cities considered in the study.

The relationship between $\mathrm{PM}_{2.5}$ exposure or meteorological factors (data are shown in Figures S1-S6 in the Supplementary material) and COVID-19 data (Figure 3) during the Spanish lockdown is shown in Figure 4. 


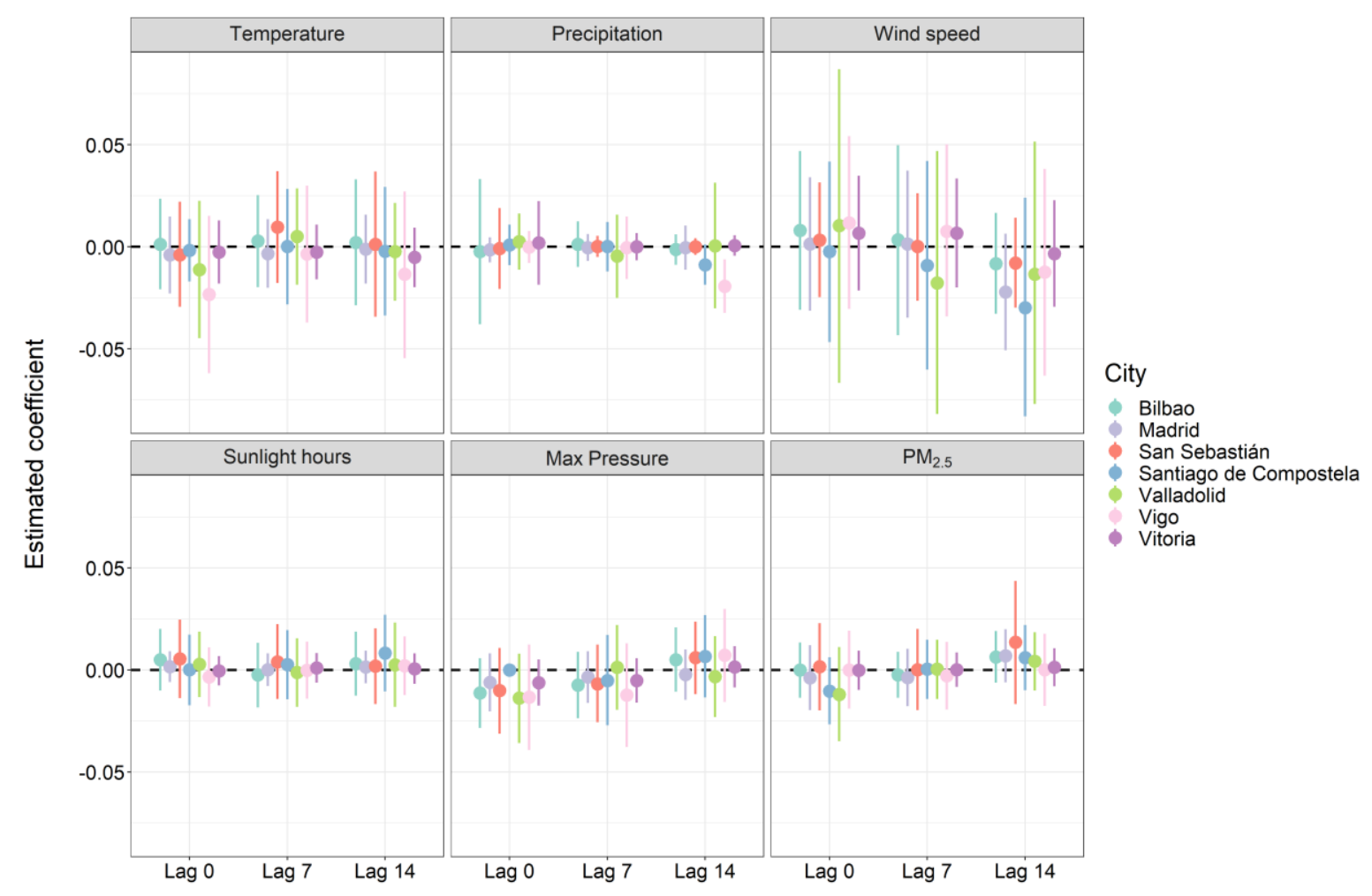

Figure 4. Effects of each environmental covariate and $\mathrm{PM}_{2.5}$ exposure on COVID-19 spread estimated for each city under study. Each dot represents the estimation of the coefficient ( $\beta$ parameter in Equation (2)), whereas the segment corresponds to the $95 \%$ credible interval associated with the estimation.

Thus, no association is observed between COVID-19 accumulated cases and $\mathrm{PM}_{2.5}$ levels or climate patterns, contrary to what we could expect according to recent results on the effect of particulate matter levels(Cole et al., 2020; Zhu et al., 2020; Zoran et al., 2020) or climate conditions (Chiyomaru and Takemoto, 2020; Sobur et al., 2020; Tobías and Molina, 2020). Anyhow, it is still unclear the relationship between COVID-19 transmission and $\mathrm{PM}_{2.5}$ exposure which is in need of further investigation (Hendryx and Luo, 2020) and many controversial results have been reported about the effect of climate on the COVID-19 spread, partly as a consequence of the different statistical methodologies chosen(Briz-Redón and 
Serrano-Aroca, 2020b). We have used univariate Poisson models accounting for the presence of temporal autocorrelation in the data. The inclusion of such a temporal term allows capturing the epidemic growth and reduces the chances of obtaining spurious or artefactual associations, which can easily arise when correlation coefficients are computed. The fact that many published studies are strongly based on correlation coefficients, together with the existing uncertainty about COVID-19 data, are sufficient reasons for still being cautious about the association between COVID-19 and the environment or $\mathrm{PM}_{2.5}$ pollution. Furthermore, the use of multivariate models that allow accounting for several of the factors (environmental or non-environmental) that are possibly implicated in COVID-19 is highly advisable, although we discarded the use of these models in this case due to the length of the time series available.

\section{Conclusions}

Air pollution was analyzed at the city-level through a regression model to determine the changes of $\mathrm{PM}_{2.5}$ during the Spanish lockdown while accounting for the effect of some meteorological factors. While the 4-week national lockdown reduced the COVID-19 accumulated cases in Spain, the results of this study show a significant decrease in $\mathrm{PM}_{2.5}$ pollution in only one city. Furthermore, no relationship between COVID-19 spread and PM 2.5 exposure or weather patterns was found during this period in Spain.

\section{Supplementary material}

The data of temperature (Figure S1), precipitation (Figure S2), wind velocity (Figure S3), sunlight time (Figure S4), the maximum pressure (Figure S5) and $\mathrm{PM}_{2.5}$ (Figure S6) levels used for the association study with COVID-19 accumulated cases for the seven cities considered in the study are shown in the Supplementary material.

\section{Acknowledgments}


medRxiv preprint doi: https://doi.org/10.1101/2020.08.09.20171041; this version posted August 19, 2020. The copyright holder for this preprint (which was not certified by peer review) is the author/funder, who has granted medRxiv a license to display the preprint in perpetuity.

It is made available under a CC-BY-NC-ND 4.0 International license .

The authors would like to acknowledge the University of Valencia for the Talent attraction VLC-CAMPUS PhD fellowship (conceded to C.B-S) and the Fundación UCV San Vicente Mártir for the economic support through Grants 2019-231-003UCV and 2020-231-001UCV (conceded to Á.S-A).

\section{References}

2008/50/CE, 2008. Directive 2008/50/EC of the European Parliament and of the Council of 21st May 2008 on ambient air quality and cleaner air for Europe.

2015/1480/UE, 2015. Directive 2015/1480/UE of the Commission of 28th August 2015 amending several annexes to Directives 2004/107/EC and 2008/50/EC laying down the rules concerning the assessment of ambient air quality.

Abdullah, S., Mansor, A.A., Napi, N.N.L.M., Mansor, W.N.W., Ahmed, A.N., Ismail, M., Ramly, Z.T.A., 2020. Air quality status during 2020 Malaysia Movement Control Order (MCO) due to 2019 novel coronavirus (2019-nCoV) pandemic. Sci. Total Environ. 729, 139022. https://doi.org/10.1016/j.scitotenv.2020.139022

Ayuntamiento de Madrid, 2020. Portal de datos abiertos del Ayuntamiento de Madrid

[WWW Document]. Bicimad. URL https://datos.madrid.es/portal/site/egob/

Briz-Redón, Á., Belenguer-Sapiña, C., Serrano-Aroca, Á., 2020. Changes in air pollution during COVID-19 lockdown in Spain: a multi-city study. J. Environ. Sci.

https://doi.org/10.1016/j.jes.2020.07.029

Briz-Redón, Á., Serrano-Aroca, Á., 2020a. A spatio-temporal analysis for exploring the effect of temperature on COVID-19 early evolution in Spain. Sci. Total Environ. 728, 138811. https://doi.org/10.1016/j.scitotenv.2020.138811

Briz-Redón, Á., Serrano-Aroca, Á., 2020b. The effect of climate on the spread of the COVID-19 pandemic: A review of findings, and statistical and modelling techniques. 
Prog. Phys. Geogr. Earth Environ. 030913332094630.

https://doi.org/10.1177/0309133320946302

Chai, G., He, H., Sha, Y., Zhai, G., Zong, S., 2019. Effect of PM2.5 on daily outpatient visits for respiratory diseases in Lanzhou, China. Sci. Total Environ. 649, 1563-1572. https://doi.org/10.1016/j.scitotenv.2018.08.384

Chen, N., Zhou, M., Dong, X., Qu, J., Gong, F., Han, Y., Qiu, Y., Wang, J., Liu, Y., Wei, Y., Xia, J., Yu, T., Zhang, X., Zhang, L., 2020. Epidemiological and clinical characteristics of 99 cases of 2019 novel coronavirus pneumonia in Wuhan, China: a descriptive study. Lancet 395, 507-513. https://doi.org/10.1016/S0140$6736(20) 30211-7$

Chiu, A.S.F., Aviso, K.B., Tan, R.R., 2020. On general principles at the sustainability science-policy interface. Resour. Conserv. Recycl. 158, 104828. https://doi.org/10.1016/j.resconrec.2020.104828

Chiyomaru, K., Takemoto, K., 2020. Global COVID-19 transmission rate is influenced by precipitation seasonality and the speed of climate temperature warming. medRxiv 2020.04.10.20060459. https://doi.org/10.1101/2020.04.10.20060459

Cole, M.A., Ozgen, C., Strobl, E., 2020. Air Pollution Exposure and Covid-19.

Conticini, E., Frediani, B., Caro, D., 2020. Can atmospheric pollution be considered a cofactor in extremely high level of SARS-CoV-2 lethality in Northern Italy? Environ. Pollut. https://doi.org/10.1016/j.envpol.2020.114465

Datos Abiertos Comunidad de Madrid, 2020. Covid 19 -TIA por Municipios y Distritos de Madrid [WWW Document]. URL https://datos.comunidad.madrid/catalogo/dataset/covid19_tia_muni_y_distritos (accessed 8.8.20). 
Dominici, F., Peng, R.D., Bell, M.L., Pham, L., McDermott, A., Zeger, S.L., Samet, J.M., 2006. Fine particulate air pollution and hospital admission for cardiovascular and respiratory diseases. J. Am. Med. Assoc. 295, 1127-1134.

https://doi.org/10.1001/jama.295.10.1127

EN 12341:2014, 2014. Ambient air: standard gravimetric measurement method for the determination of PM10 and PM2.5 mass concentration of suspended particulate matter.

Euskadi.eus, 2020. Euskadi.eus - Toda la información, trámites y servicios del Gobierno Vasco [WWW Document]. URL https://www.euskadi.eus/inicio/

Euskadi, 2020. Informes con la actualización de datos sobre la evolución del nuevo coronavirus COVID-19 [WWW Document]. URL https://www.euskadi.eus/boletinde-datos-sobre-la-evolucion-del-coronavirus/web01-a2korona/es/ (accessed 8.8.20).

Faridi, S., Yousefian, F., Niazi, S., Ghalhari, M.R., Hassanvand, M.S., Naddafi, K., 2020. Impact of SARS-CoV-2 on Ambient Air Particulate Matter in Tehran. Aerosol Air Qual. Res. 20, 1805-1811. https://doi.org/10.4209/aaqr.2020.05.0225

Fenech, S., Aquilina, N.J., 2020. Science of the Total Environment Trends in ambient ozone, nitrogen dioxide, and particulate matter concentrations over the Maltese Islands and the corresponding health impacts. Sci. Total Environ. 700, 134527. https://doi.org/10.1016/j.scitotenv.2019.134527

Fox, J., Weisberg, S., 2018. An R Companion to Applied Regression. SAGE Publications. Galicia, 2020. El mapa y la evolución del coronavirus en Galicia [WWW Document]. URL https://afondo.farodevigo.es/galicia/el-mapa-del-coronavirus-en-galicia.html (accessed 8.8.20).

García, M.Á., Sánchez, M.L., de los Ríos, A., Pérez, I.A., Pardo, N., Fernández-Duque, B., 
2019. Analysis of PM10 and PM2.5 Concentrations in an Urban Atmosphere in Northern Spain. Arch. Environ. Contam. Toxicol. 76, 331-345.

https://doi.org/10.1007/s00244-018-0581-3

Grolemund, G., Wickham, H., 2011. Dates and Times Made Easy with lubridate. J. Stat. Softw. 40, 1-25.

Hendryx, M., Luo, J., 2020. COVID-19 prevalence and fatality rates in association with air pollution emission concentrations and emission sources. Environ. Pollut. 265, 115126. https://doi.org/10.1016/j.envpol.2020.115126

Hoque, M.M., Ashraf, Z., Kabir, H., Sarker, E., 2020. Meteorological Influences on Seasonal Variations of Air Pollutants ( SO2, NO2, O3, CO, PM2.5 and PM10) in the Dhaka Megacity. Am. J. Pure Appl. Biosci. 2, 15-23. https://doi.org/10.34104/ajpab.020.15023

Horne, B.D., Joy, E.A., Hofmann, M.G., Gesteland, P.H., Cannon, J.B., Lefler, J.S., Blagev, D.P., Kent Korgenski, E., Torosyan, N., Hansen, G.I., Kartchner, D., Arden Pope, C., 2018. Short-term elevation of fine particulate matter air pollution and acute lower respiratory infection. Am. J. Respir. Crit. Care Med. 198, 759-766. https://doi.org/10.1164/rccm.201709-1883OC

INE, 2019. Instituto Nacional de Estadí-stica. (National Statistics Institute) [WWW Document]. URL https://www.ine.es/dynt3/inebase/es/index.htm?padre=517\&capsel=522 ISCIII, n.d. Situación de COVID-19 o Coronavirus en España. [WWW Document]. JCyL, A. de datos abiertos, 2020. Situación epidemiológica del coronavirus en Castilla y León [WWW Document]. URL https://analisis.datosabiertos.jcyl.es/pages/coronavirus/descarga-de-datasets\#situacin- 
actual (accessed 8.8.20).

Junta de Castilla y León, 2020. ESCO - Consulta de Datos de la Red de Calidad del Aire [WWW Document].

Lang, D.T., 2020. XML: Tools for Parsing and Generating XML Within R and S-Plus.

Lang, D.T., the CRAN team, 2015. RCurl: General Network (HTTP/FTP/...) Client

Interface for R. R package version 1.95-4.7.

Lemou, A., Rabhi, L., Merabet, H., Ladji, R., Nicolas, J.B., Bonnaire, N., Mustapha, M.A., Dilmi, R., Sciare, J., Mihalopoulos, N., Yassaa, N., 2020. Chemical characterization of fine particles (PM2.5) at a coastal site in the South Western Mediterranean during the ChArMex experiment. Environ. Sci. Pollut. Res. 27, 20427-20445.

https://doi.org/10.1007/s11356-020-08168-7

Lindgren, F., Rue, H., 2015. Bayesian spatial modelling with R-INLA. J. Stat. Softw. 63, 1-25. https://doi.org/10.18637/jss.v063.i19

Liu, B., Sun, X., Zhang, J., Bi, X., Li, Y., Li, L., Dong, H., Xiao, Z., Zhang, Y., Feng, Y., 2020. Characterization and Spatial Source Apportionments of Ambient PM10 and PM2.5 during the Heating Period in Tian’ jin , China. Aerosol Air Qual. Res. 20, 113. https://doi.org/10.4209/aaqr.2019.06.0281

Liu, C., Chen, R., Sera, F., Vicedo-Cabrera, A.M., Guo, Y., Tong, S., Coelho, M.S.Z.S., Saldiva, P.H.N., Lavigne, E., Matus, P., Ortega, N.V., Garcia, S.O., Pascal, M., Stafoggia, M., Scortichini, M., Hashizume, M., Honda, Y., Hurtado-Díaz, M., Cruz, J., Nunes, B., Teixeira, J.P., Kim, H., Tobias, A., Íñiguez, C., Forsberg, B., Åström, C., Ragettli, M.S., Guo, Y.L., Chen, B.Y., Bell, M.L., Wright, C.Y., Scovronick, N., Garland, R.M., Milojevic, A., Kyselý, J., Urban, A., Orru, H., Indermitte, E., Jaakkola, J.J.K., Ryti, N.R.I., Katsouyanni, K., Analitis, A., Zanobetti, A., Schwartz, J., Chen, J., 
Wu, T., Cohen, A., Gasparrini, A., Kan, H., 2019. Ambient particulate air pollution and daily mortality in 652 cities. N. Engl. J. Med. 381, 705-715.

https://doi.org/10.1056/NEJMoa1817364

Ludecke, D., 2016. sjPlot: Data visualization for statistics in social science. R package version 2.0.1, https://CRAN.R-project.org/package=sjPlot.

Mahato, S., Pal, S., Ghosh, K.G., 2020. Effect of lockdown amid COVID-19 pandemic on air quality of the megacity Delhi, India. Sci. Total Environ. 730, 139086. https://doi.org/https://doi.org/10.1016/j.scitotenv.2020.139086

Manisalidis, I., Stavropoulou, E., Stavropoulos, A., Bezirtzoglou, E., 2020. Environmental and Health Impacts of Air Pollution: A Review. Front. Public Heal. https://doi.org/10.3389/fpubh.2020.00014

Mao, J., Wang, L., Lu, C., Liu, J., Li, M., Tang, G., Ji, D., Zhang, N., Wang, Y., 2020. Meteorological mechanism for a large-scale persistent severe ozone pollution event over eastern China in 2017. J. Environ. Sci. 92, 187-199. https://doi.org/10.1016/j.jes.2020.02.019

Mehmood, K., Saifullah, Iqbal, M., Abrar, M.M., 2020. Can exposure to PM2.5 particles increase the incidence of coronavirus disease 2019 (COVID-19)? Sci. Total Environ. https://doi.org/10.1016/j.scitotenv.2020.140441

Ministerio de Medio Ambiente y Medio Rural y Marino. AEMET, 2011. Atlas Climático Ibérico Iberian Climate Atlas Gobierno De España.

Nicolás, J., Lucarelli, F., Galindo, N., Yubero, E., Crespo, J., Calzolai, G., Nava, S., 2020. Impact of traffic flows and meteorological events on the hourly elemental composition of fine and coarse particles at an urban site. Aerosol Air Qual. Res. 20, 991-1001. https://doi.org/10.4209/aaqr.2019.09.0437 
medRxiv preprint doi: https://doi.org/10.1101/2020.08.09.20171041; this version posted August 19, 2020. The copyright holder for this preprint (which was not certified by peer review) is the author/funder, who has granted medRxiv a license to display the preprint in perpetuity.

It is made available under a CC-BY-NC-ND 4.0 International license .

Radzka, E., 2020. The Effect of Meteorological Conditions on Air Pollution in Siedlce. J. Ecol. Eng. 21, 97-104. https://doi.org/10.12911/22998993/113074

Rue, H., Martino, S., Chopin, N., 2009. Approximate Bayesian inference for latent Gaussian models by using integrated nested Laplace approximations. J. R. Stat. Soc. Ser. B Stat. Methodol. 71, 319-392. https://doi.org/10.1111/j.1467-9868.2008.00700.x Sarkis, J., Cohen, M.J., Dewick, P., Schröder, P., 2020. A Brave New World: Lessons from the COVID-19 Pandemic for Transitioning to Sustainable Supply and Production. Resour. Conserv. Recycl. 104894. https://doi.org/10.1016/j.resconrec.2020.104894

Sedlmaier, N., Hoppenheidt, K., Krist, H., Lehmann, S., Lang, H., Büttner, M., 2009. Generation of avian influenza virus (AIV) contaminated fecal fine particulate matter (PM2.5): Genome and infectivity detection and calculation of immission. Vet. Microbiol. 139, 156-164. https://doi.org/10.1016/j.vetmic.2009.05.005

Sharma, S., Zhang, M., Anshika, Gao, J., Zhang, H., Kota, S.H., 2020. Effect of restricted emissions during COVID-19 on air quality in India. Sci. Total Environ. 728, 138878. https://doi.org/10.1016/j.scitotenv.2020.138878

Shi, C., Yuan, R., Wu, B., Meng, Y., Zhang, Hao, Zhang, Hongqun, Gong, Z., 2018. Meteorological conditions conducive to PM2.5 pollution in winter 2016/2017 in the Western Yangtze River Delta, China. Sci. Total Environ. 642, 1221-1232. https://doi.org/10.1016/j.scitotenv.2018.06.137

Sobur, M.A., Islam, M.S., Haque, M.E., Rahman, A.T., Islam, M.T., Toniolo, A., Rahman, M.T., 2020. Influence of temperature and relative humidity on the occurrence of COVID-19 pandemic: An observational study in 57 countries. medRxiv 2020.05.03.20089342. https://doi.org/10.1101/2020.05.03.20089342

Team, R.C., 2020. R: A language and environment for statistical computing. 
Tobías, A., 2020. Evaluation of the lockdowns for the SARS-CoV-2 epidemic in Italy and Spain after one month follow up. Sci. Total Environ. 138539. https://doi.org/10.1016/j.scitotenv.2020.138539

Tobías, A., Molina, T., 2020. Is temperature reducing the transmission of COVID-19? Environ. Res. https://doi.org/10.1016/j.envres.2020.109553

UK Dep. for Environment Food and Rural Affairs, 2020. Site environment types - Defra, UK.

Venter, Z.S., Aunan, K., Chowdhury, S., Lelieveld, J., 2020. COVID-19 lockdowns cause global air pollution declines with implications for public health risk Authors Affiliations : ORCIDs : Key words : Introduction : medRxiv. https://doi.org/10.1101/2020.04.10.20060673

Viana, M., Rizza, V., Tobías, A., Carr, E., Corbett, J., Sofiev, M., Karanasiou, A., Buonanno, G., Fann, N., 2020. Estimated health impacts from maritime transport in the Mediterranean region and benefits from the use of cleaner fuels. Environ. Int. 138. https://doi.org/10.1016/j.envint.2020.105670

Wang, M., Jiang, A., Gong, L., Luo, L., Guo, W., Li, Chuyi, Zheng, J., Li, Chaoyong, Yang, B., Zeng, J., Chen, Y., Zheng, K., Li, H., 2020. Temperature significant change COVID-19 Transmission in 429 cities. medRxiv 2020.02.22.20025791. https://doi.org/10.1101/2020.02.22.20025791

Wang, P., Guo, H., Hu, J., Kota, S.H., Ying, Q., Zhang, H., 2019. Responses of PM 2.5 and O 3 concentrations to changes of meteorology and emissions in China. Sci. Total Environ. 662, 297-306. https://doi.org/10.1016/j.scitotenv.2019.01.227

Wang, P., Chen, K., Zhu, S., Wang, Peng, Zhang, H., 2020. Severe air pollution events not avoided by reduced anthropogenic activities during COVID-19 outbreak. Resour. 
Conserv. Recycl. 158, 104814. https://doi.org/10.1016/j.resconrec.2020.104814

WHO, 2020a. Director-General's opening remarks at the media briefing on COVID-19 - 11 March 2020 [WWW Document]. URL https://www.who.int/dg/speeches/detail/whodirector-general-s-opening-remarks-at-the-media-briefing-on-covid-19---11-march2020

WHO, 2020b. Coronavirus disease (COVID-19) Pandemic [WWW Document]. World Heal. Organ. URL https://www.who.int/emergencies/diseases/novel-coronavirus-2019

Wickham, H., 2016. ggplot2: Elegant Graphics for Data Analysis. Springer-Verlag New York.

World Health Organization, 2018. Ambient ( outdoor ) air pollution [WWW Document]. WHO. URL https://www.who.int/news-room/fact-sheets/detail/ambient-(outdoor)-airquality-and-health

Xiao, Y., Murray, J., Lenzen, M., 2018. International trade linked with disease burden from airborne particulate pollution. Resour. Conserv. Recycl. 129, 1-11. https://doi.org/10.1016/j.resconrec.2017.10.002

Xu, Y., Yang, L., Wang, X., Zheng, M., Li, C., Zhang, A., 2020. Risk evaluation of environmentally persistent free radicals in airborne particulate matter and in fl uence of atmospheric factors. Ecotoxicol. Environ. Saf. 196, 110571. https://doi.org/10.1016/j.ecoenv.2020.110571

Xunta de Galicia, 2020. Calidade do Aire de Galicia [WWW Document]. URL https://www.meteogalicia.gal/Caire/index.action

Yousefian, F., Faridi, S., Azimi, F., Aghaei, M., Shamsipour, M., 2020. Temporal variations of ambient air pollutants and meteorological influences on their concentrations in Tehran during 2012 - 2017. Sci. Rep. 10, 292. 
https://doi.org/10.1038/s41598-019-56578-6

Zhu, Y., Xie, J., Huang, F., Cao, L., 2020. Association between short-term exposure to air pollution and COVID-19 infection: Evidence from China. Sci. Total Environ. 727, 138704. https://doi.org/10.1016/j.scitotenv.2020.138704

Zoran, M.A., Savastru, R.S., Savastru, D.M., Tautan, M.N., 2020. Assessing the relationship between surface levels of PM2.5 and PM10 particulate matter impact on COVID-19 in Milan, Italy. Sci. Total Environ. 738, 139825.

https://doi.org/10.1016/j.scitotenv.2020.139825 